\title{
ПОЛЬША В ПОЛИТИКЕ МИНИСТРОВ ИНОСТРАННЫХ ДЕЛ РФ А.В. КОЗЫРЕВА И Е.М. ПРИМАКОВА: СРАВНИТЕЛЬНЫЙ АНАЛИЗ
}

\begin{abstract}
Аннотация: В статье исследуется процесс формирования и развития российско-польских отношений в 1990-е годы. На основе компаративного анализа делается вывод о том, что между внешнеполитическими курсами А.В. Козырева и Е.М. Примакова существовала определённая преемственность в отношении к странам Восточной Европь. Автор приходит к выводу о том, что после 1993 г. А.В. Козырев постепенно отказывался от идеалистических подходов и переходил к прагматизации внешней политики России. В дальнейшем эта линия была продолжена и расширенна Е.М. Примаковым.
\end{abstract}

Ключевые слова: политология, польша, Россия, Примаков, Козырев, НАТО, ОБСЕ, политика, международнье отноешния, конфликтьл.

B нешняя политика Российской Федерации в 1990-е гг. формировалась в условиях новой геополитической реальности, вызванной роспуском Варшавского договора и распадом Советского Союза. Определение основных подходов российской внешней политики происходило в условиях глубинных социо-политических, экономических и институциональных изменений, проходивших как в самой России, так и в других странах бывшего социалистического лагеря.

Ключевую роль в процессах определения и изменения внешнеполитической линии Российской Федерации играли министры иностранных дел А.В. Козырев (1990-96) и Е.М. Примаков (1996-98). Сравнительное исследование их подходов к российско-польским отношениям позволяет на конкретно-историческом материале выявить основные тенденции российской внешней политики 1990-х гг., что важно для формирования всесторонней картины истории России периода президентства Б.Н. Ельцина (1991-99) и для укрепления российско-польских отношения на современном этапе.

Анализ публичных заявлений, коммюнике и международных договоров, заключённых А.В. Козыревым или подготовленных при его участии, позволяет выделить в его подходах к российско-польским отношениям два этапа. На первом (1990-93) для политики А.В. Козырева приоритетами было признание за Россией статуса составной части евроатлантического мира и преодоление биполярного разделения, характерного для времён «холодной войны», утверждение принципа «единого мира» в международных отношениях [Козырев, 1995]. Стремясь к достижению этих целей, российская дипломатия в тот момент основным направлением для себя выбрала развитие диалога по линии Москва-Вашингтон, контакты с Западной
Европой стояли на втором месте, а Восточно-Европейскому региону и в частности Польше уделялось незначительное внимание. Несмотря на это, в целях развития партнёрства России-США и формирования «единого мира» А.В. Козырев на данном этапе с пониманием относился к проблемам, которые польская сторона поднимала в рамках диалога с Москвой. Заключение в 1992 г. договора «О дружественном и добрососедском сотрудничестве» продемонстрировало готовность Москвы отказаться от логики блокового мира и признать равноправие своих отношений с Варшавой [Бюллетень международных договоров, 1993, № 7, С. 72-78]. Ключевым вопросом, характеризующим российско-польские отношения данного этапа, стала проблема вывода российских вооружённых сил с территории Польши. Несмотря на возникавшие трудности, в том числе обусловленные внутриполитическими проблемами в обеих странах, российская дипломатия обеспечила выполнение всех своих обязательств, данных польской стороне. Принципиально важным было то, что Россия согласилась вывести войска без предъявления каких-либо дополнительных требований, ограничивающих польский суверенитет на международной арене.

Второй этап (1994-96) руководства А.В. Козырева МИД РФ характеризуется прагматизацией отношений России-США и нарастающим беспокойством Москвы относительно перспектив проникновения НАТО в регион Восточной Европы. Если в период администрации Дж. Буша (1989-93) вопрос о вступлении стран Восточной Европы и в том числе Польши в НАТО не находил уверенной поддержки в США, то с приходом администрации Б. Клинтона (1993-2001) такая перспектива стала реальной [Clinton, 1993]. На встрече с новым президентом США в 1993 г. президента Польши Л. Валенса (1990-95) добился принципиаль- 


\section{Внешняя политика России / Foreign policy of Russia}

ного согласия на вступление своей страны в НАТО. [Wałęsa, 2007]. Это вызвало неоднозначную реакцию российской стороны. Б.Н. Ельцин в ходе своего визита в Варшаву в августе 1993 г. заявил о том, что Россия не возражает против атлантической интеграции Польши, однако глава российского МИД стал всё более критически оценивать перспективы расширения альянса на восток и включение в него Польши [Дипломатический вестник. Сентябрь 1993. № 17-18]. Основным аргументом А.В. Козырева было то, что НАТО пока не сумело адаптироваться к новой геополитической реальности и продолжает действовать в логике «холодной войны». В целом основной осью отношений Варшавы и Москвы на этом этапе стало противодействие российской дипломатии скорому вступлению Польши, Венгрии и Чехии в НАТО. Стремление Польши и других стран Вышеградской группы к атлантической интеграции стало одним из основных факторов, которые повлияли на корректировку А.В. Козыревым своей политики в отношениях с США. С конца 1994 г., после посещения саммита НАТО и переговоров со своим американским коллегой У. Кристофером (1993-1997), он признал, что отношения двух стран должны превратиться в нечто новое, фактически лишённое вильсоновского идеализма [Коммерсант, №230, 1994]. При этом Москва не проявляла практически никакого интереса к европейскому направлению интеграции Польши: сближению Брюсселя и Варшавы. Непопулярность А.В. Козырева и приближающиеся президентские выборы привели к тому, что Б.Н. Ельцин был вынужден отправить в отставку многолетнего члена своей команды.

Приход в самом начале 1996 г. на Смоленскую площадь Е.М. Примакова, имевшего репутацию сторонника евразийской интеграции и последовательного противника однополярного мира, обозначил новый этап российской внешней политики. Уже в марте Е.M. Примаков совершил первый за восемь лет официальный визит в Польшу для переговоров с президентом А. Квасневским (1995-2005), продемонстрировав тем самым своё внимание к диалогу с Варшавой. В ходе переговоров ключевой вновь стала проблема вступления Польши в НАТО - Москва выразила своё принципиальное несогласие с этой перспективой. При этом Е.М. Примаков пытался противопоставить атлантической солидарности европейскую и в целом позитивно высказался о возможностях укрепления европейских структур и включения в них новых членов, в т.ч. Польши [Коммерсант, №43, 1996]. Это вписывалось в его концепцию многополярного мира, где наравне в США должны существовать и другие центры силы, например, Европа. [Примаков, 1996]. Тем не менее, именно в период руководства Е.М. Примаковым МИД России произошло т. н. «четвёртое расширение»
НАТО, Польша стала членом альянса. Это, однако, не привело к критическому похолоданию в российскопольских отношениях. Руководствуясь принципами Realpolitik, E.M. Примаков принял как неоспоримый факт новую политическую реальность и продолжил налаживание конструктивного диалога с польской стороной. Высоко оценивая перспективы развития двусторонних гуманитарных и экономических контактов, Е.М. Примаков стал одним из инициаторов заключения «Соглашения о молодёжном сотрудничестве», способствовал интенсификации экономических отношений Калининградской области с Польшей. В этот же период Е.М. Примаков выступает сторонником ведения диалога между Россией и Польшей в рамках ОБСЕ, где польской стороне предстояло председательствовать в 1998 г. В этой связи можно говорить и об определённом сотрудничестве между Польшей и Россией на белорусском направлении - именно в 1998 г. было открыто официальное представительство ОБСЕ в Минске [Белорусский журнал международного права и международных отношений, 2002, №1]. Глава российского МИД сумел выстроить рабочие отношения со своим польским коллегой Б. Геремеком (1997-2000), которого стремился привлечь к решению проблемы Косово совместно с Россией, создавая таким образом позитивную повестку в переговорах Москвы и Варшавы. Югославский кризис и внутриполитическая ситуация в России привели к тому, что Е.М. Примаков не смог реализовать все свои инициативы в отношении Польши, а в сентябре 1998г. покинул пост главы МИД и возглавил Правительство России.

Сравнивая место Польши во внешнеполитических подходах А.В. Козырева и Е.М. Примакова, следует отметить, что для обоих министров российско-польские отношения никогда, разумеется, не стояли на первом месте. Однако если для А.В. Козырева диалог с Варшавой был важен в первую очередь в более широком контексте отношений России с США и с Западом в целом, то для Е.М. Примакова польское направление имело самостоятельную ценность и было одним элементов многовариантности российской дипломатии, её стремления строить многополярный мир.

Несмотря на существующую в публицистике традицию жёсткого противопоставления курсов А.В. Козырева и Е.М. Примакова, пример их подходов к Польше показывает, что такие оценки не вполне верны. Если на первом этапе «козыревская» дипломатия в отношении Польши придерживалась стратегии построения «единого мира» и избавления Польши от российского военного присутствия и ограничений внешнего суверенитета - последствия биполярного разделения плане- 


\section{Международные отношения International Relations}

ты. То на втором этапе руководства А.В. Козыревым российским МИД, когда стала очевидным неготовность Запада в полной мере отказаться от логики «холодной войны», Москва начала активно протестовать против поспешного включения Польши в атлантические структуры. Фактически уже в этот период А.В. Козырев, не отказываясь от приоритета российско-американского диалога, стал предпринимать шаги по активизации контактов с другими политическими центрами, в т.ч. с Варшавой. Е.M. Примаков, возглавив российскую дипломатию, сделал основой своей доктрины укрепление многополярности мира, недопущение военно-стратегического диктата со стороны США и НАТО. Можно утверждать, что он продолжил, расширил и укрепил уже намеченную А.В. Козыревым линию по крити- ке поспешного расширения Североатлантического альянса на восток. Также важно отметить, что, несмотря на утвердившееся в широких кругах мнение о конфронтационности по отношению к Западу «доктрины Примакова», он сумел сохранить и укрепить отношения с Варшавой даже после её вступления в НАТО. Этим была продемонстрирована готовность России строить партнёрские отношения с членами североатлантического сообщества, что является одним из ключевых аспектов «доктрины Козырева». Таким образом, на примере российско-польских отношений в этот период можно говорить о существовании (при всех отличиях) преемственности между курсами обоих министров, а также ещё раз отметить сохраняющуюся актуальность линии Е.М. Примакова на строительство многополярного мира.

\section{Список литературы:}

1. Белорусский журнал международного права и международных отношений. 2002. №1. С. 38-43.

2. Бюллетень международных договоров. 1993. № 7. С. 72-78.

3. Дипломатический вестник. Сентябрь, 1993. № 17-18. С. 15-16.

4. Козырев А. В. Преображение. М., 1995.

5. Коммерсант. 1994. №230.

6. Коммерсант. 1996. №43.

7. Примаков Е.М. Международные отношения накануне XXI века: проблемы, перспективы. На горизонте многополюсный мир // Международная жизнь. 1996. №10. С. 3-13.

8. Clinton W. Reforming the UN / Vital Speeches of the Day. 993, October 15. P. 10.

9. Wałęsa 1. Moja III RP. Straciłem cierpliwość. Warszawa, 2007. 